\title{
Differences between Flexible and Conventional Remedial Learning Models towards Food and Beverage Analysis Course Learning Outcome
}

\author{
Endang Tri Wahyuni Maharani' ${ }^{1}$, Rasdi Ekosiswoyo ${ }^{2}$, Supartono $^{3}$, Kardoyo $^{4}$ \\ ${ }_{1,2,3,4}$ Graduate School, Universitas Negeri Semarang, Indonesia \\ ${ }^{1}$ Corresponding email: endangtm@unimus.ac.id
}

\begin{abstract}
Remedial learning is a learning system in which the lessons are divided into small portions to be put together in a sequence to reach better outcome. The aims of this research were: (1) to know the influence of using flexible and conventional remedial study towards students' learning outcome, (2) to know the influence of vocational and academic educational orientation towards the students' learning outcome, (3) to know the interaction between the use of remedial study model and educational orientation towards the students' learning outcome. The method used in this research was an experimental method which involved two classes. The remedial study of the experimental class used the flexible remedial method, while the control class used the conventional remedial method. The conclusions were: (1) There was a significant difference in learning outcome between students who were given flexible and conventional remedial learning. Students who received flexible remedial learning gained higher outcome than students with conventional remedial learning.; (2) There were significant differences on the learning outcome especially on the cognitive aspect between students with vocational and academic educational orientation ability. It was found that the higher outcome went to the students with vocational educational orientation.; (3) There was no interaction between the remedial learning model and the educational orientation towards the learning outcome.
\end{abstract}

Keywords: Remedial, Flexible and Conventional Model, Learning Outcome

\section{Introduction}

Remedial learning is a learning system in which the lessons are divided into small portions to be put together in a sequence to reach better outcome. In doing this, students are independently doing some tests to immediately get feedback, and the result is shared as soon as possible (Chen,L-H., 2011). It is believed that remedial learning is a form of didactic support with the purpose to improve learning outcome. According to Khouyibaba (2015); remedial learning is a method to improve students' weaknesses, mistakes or shortcomings to be discovered by themselves based on the continuous given evaluation. Thus, students are not required to redo all the lessons, but only on the weak parts.

Food \& Beverage Analysis is one of the fundamental subjects as it is categorized in the Program Final Evaluation. Based on data collected from Academic Assessment Center in Nursing and Health Faculty (Fikkes) of Universitas Muhammadiyah Semarang (Unimus), there were a huge number of remedial students for that particular subject. The data indicated that not only the subject was difficult, but also there was a need of getting a lot of detail to understand the lesson.

The remedial model currently implemented in Unimus Health Analyst Diploma III Program is the Conventional model, in which students are given a test, an assignment and Q\&A without any learning process. It is clearly shown that lecturers ignore the level of difficulty faced by the students, while not all students encounter the same level of difficulty. This fact obviously deviates from the purposes of remedial learning which aims to improve on weaknesses, mistakes, or shortcomings of the students and as a form of "healing" process from learning obstruction (Dahar,R.W.,2011).

Remedial learning using Flexible Model is different from the Conventional one because students will receive lesson according to the level of difficulty encountered by students. It means, all students will get a different lesson from the others. This method will be more flexible for students because lesson is given in a different way, including the module, Q\&A, independent learning and or other supporting media.

Success in understanding the lesson is the main purpose to be achieved throughout the learning process, which is known as "Educational Orientation." Align with Taylor's statement (1983) who categorized 3 (three) main educational orientations, namely, vocational, academic, and personal. Those three categories have different type of interest on different science intrinsically and extrinsically. 
Vocational educational orientation has an external purpose to gain needed qualification and its internal motive is to gain an effective training relevant to career advancement. Meanwhile, academic educational orientation has an external purpose to level up education and internal purpose to pursue knowledge for personal purposes. Further, any different educational orientations show students' motivation to continue to higher educational level.

Previous research has been conducted on remedial learning by Raval,H.,et al (2014); Saine,N.L., et al (2010); Chen,L-H.,(2011); Toll et al (2013); C-Y.Dai.,et al (2015) and Kasran et al (2012).

Based on those reasonings, the researchers addressed several issues: (1) the influence of the use of flexible and conventional remedial learning towards students' learning outcome, (2) the influence of vocational and academic educational orientation towards the students' learning outcome, and (3) to find whether there is any interaction between the use of remedial learning model (flexible and conventional) and educational orientation (vocational and academic) towards the students' learning outcome.

\section{Methods}

This research was categorized as an experimental research which used quantitative approach and included two classes, experimental class in remedial learning using flexible remedial model and control class in remedial learning using conventional remedial learning (Sugiyono, 2010). Both classes were assumed same in all aspects, but different in the remedial treatment.

The independent variable in this research was conventional remedial model (conventional dan flexible) and educational orientation (vocational dan academic), while the dependent variable was learning outcome on Food \& Beverage Analysis subject. The population were semester IV students of Unimus Health Analyst Diploma III Program, Faculty of Nursing and Health batch $2016 / 2017$ as many as two classes, with 34 students in each class.

The research used instruments in the form of learning implementation plan and data acquisition instrument, namely AUM PTSDL (Prayitno et al, 1997) and cognitive, affective, and psychomotoric learning outcome tests. In addition, prior using in data acquisition, the learning outcomes test has been trialled to other classes serving as subjects. The validity test showed that from 35 questions, there were 10 questions that did not meet the validity requirements and 25 items have fulfilled the validity requirements so that the 25 items were used for data collection in the field. The reliability of the test was 0.802 with high criteria. The hypotheses proposed were: 1) there are differences in learning outcomes for students given conventional and flexible remedial learning model; 2) there are differences in students' learning outcomes that have an academic and vocational educational orientation; and 3) there is an interaction between conventional and flexible remedial learning with an educational orientation towards students' learning outcomes.

Further, the technical data analysis applied were a double comparison with the normality test stage, homogeneity test, hypothesis testing including two-way variable analysis model and data acquisition from the summary of two-way variation analysis. The formula is: $\mathrm{Xijk}=\mu+\alpha \mathrm{i}$ $+\beta \mathrm{j}+(\alpha \beta) \mathrm{ij}+\varepsilon \mathrm{ijk}$.

\section{Results and Discussion}

The data obtained from research outcome was in a form of cognitive value and analized using variance of two different cells analysis, proceeded by further testing. From Anava result of students' cognitive ability, the researchers obtained the following values in the following table $1 \& 2$.

Table 1. Summary of Two- ways Anava on Cognitive Ability

\begin{tabular}{|c|c|c|c|c|c|c|}
\hline Source & $\pi \mathrm{K}$ & D* & RK & $F_{\text {obt }}$ & $\mathrm{F} \alpha$ & Decision \\
\hline Tchngig mithd $(\Lambda)$ & 2311,3758 & 1 & 2311,3758 & 14,4784 & 3,98 & $\mathrm{H}_{0 \mathrm{~A}}$ rejected \\
\hline Edu. Orient. (B) & 700,5523 & 1 & 700,5523 & 4,3882 & 3,98 & $\mathrm{H}_{\mathrm{BB}}$ rejected \\
\hline Interaction & 307,0008 & 1 & 307,0008 & 19230 & 3,98 & $\mathrm{H}_{0, \mathrm{~B}}$ \\
\hline Standard Error & 10217,1528 & 64 & 159,6430 & - & - & accepted \\
\hline Total & 13536,0817 & 67 & - & - & - & - \\
\hline
\end{tabular}

Table 2. Summary of Two-ways Anava on Affective Ability

\begin{tabular}{|c|c|c|c|c|c|c|}
\hline Source. & JK & $\mathrm{Dk}$ & RK & $F_{d s}$ & $\mathrm{Fa}$ & Decision \\
\hline Tehng Mthd (A) & 9,01359330 & 1 & 9,0135933 & 0,56 & 3,98 & $\mathrm{H}_{\mathrm{S}}$ Accepted \\
\hline Edt. Orient (B) & 1053,74370 & 1 & 1053,7437 & 65.83 & 3,98 & $\mathrm{H}_{3}$ Rejected \\
\hline Interaction & 17878,0612 & 1 & 17878,061 & 11,16 & 398 & $\mathrm{H}_{\text {wa }}$ Rejected \\
\hline Standard Error & 1024,35059 & 64 & 1024,2505 & - & - & - \\
\hline Total & 19965,1691 & 67 & - & - & $\cdot$ & - \\
\hline
\end{tabular}


Table 3. Summary of Two-ways Anava on Psychomotoric Ability

\begin{tabular}{|c|c|c|c|c|c|c|}
\hline Source & $\sqrt{K}$ & $\mathrm{Dk}$ & $\mathrm{RK}$ & $F_{\text {ots }}$ & $\mathrm{F} a$ & Decision \\
\hline Tchng Mithd (A) & 8134,89350 & 1 & 8134,8935 & 40,45 & 3,98 & $\mathrm{H}_{0 \alpha}$ rejected \\
\hline Edu. Orient (B) & 2245,62444 & 1 & 2245,6244 & 11,13 & 3,98 & $\mathrm{H}_{0 \mathrm{a}}$ rejected \\
\hline Interaction & 36625,1884 & 1 & 36625,188 & 18,16 & 3,98 & $\mathrm{H}_{\mathrm{OAB}}$ rejected \\
\hline Standard Error & 1290,29109 & 64 & 1290,2910 & . & . & . \\
\hline Total & 48295,9974 & 69 & - & - & - & - \\
\hline
\end{tabular}

Tabel 4. Summary of Two-ways Anava on Cognitive Ability Within The Row

\begin{tabular}{|c|c|c|c|c|c|c|}
\hline Cocmparisx & $\left(x_{i}-x \bar{y}\right)^{2}$ & $1 / \mathrm{ni}+1 / \mathrm{ij}$ & RKG & $F$ & Critic & Docision \\
\hline$\mu \mathrm{I} v \omega 2$ & $545,7+15$ & 0,0488 & 159,6430 & 70,0795 & 398 & Rejestat \\
\hline
\end{tabular}

Table 5. Summary of Two-ways Anava on Cognitive Ability Within The Column

\begin{tabular}{|c|c|c|c|c|c|c|}
\hline Comparisen & $(X i-X j)^{2}$ & 1/hit1/inj & RKG & F & Critic & Decision \\
\hline$\mu 15 \mu \mu 2$ & 165,4082 & 0,0488 & 159,6430 & 21,2277 & 398 & Rejated \\
\hline
\end{tabular}

\section{First Hypothesis}

The results of two-way anava statistical calculation experimental group (flexible remedial learning) and control group (conventional remedial learning) obtained FA = 14.4784> $\mathrm{F} \neg$ table $=3.98$ so that the null hypothesis was rejected and the alternative hypothesis was accepted. This meant that there were differences in the influence of the use of flexible and conventional remedial learning methods towards students' cognitive abilities on the subject of protein, fat, and carbohydrate analyzes. Anava advanced test between columns obtained Fi.j $=21.2277>$ F0.05 $=3.98$ then hypothesis rejected. This showed that there was a significant difference between column A1 (flexible remedial) and column A2 (conventional remedial). Based on tables 4 and 5 it could be seen that cognitive ability using flexible remedial learning method had higher average than the class given conventional method.

The use of flexible remedial learning model provided an opportunity for students to actively participate in learning so that their creativity, liveliness and thinking skills of students were more developed than conventional learning that less involving students' activity in learning. In the conventional learning, where the students' potential was suppressed, it was necessary to make learning innovation by using a flexible model. This model provided convenience to students in understanding and mastering concepts and understanding the matter of calculation. The above statement is similar with flexible learning by Tinkers (1999), that is, remediation using flexible method is applied where students only repeat the lesson that is considered difficult, so in remediation students do not need to repeat all the lessons.

In affective ability it was known that the value of $\mathrm{FA}=0.56<$ Ftabel $=3.98$, so the null hypothesis was accepted and the alternative hypothesis was rejected. It meant that there was no effect on the use of flexible and conventional remedial learning methods on affective ability on the subject of protein, fats and carbohydrates analysis. For more, psychomotoric ability showed that the value of $\mathrm{FA}=40.35>$ Ftabel $=$ 3.98 , so the null hypothesis was rejected and alternative hypothesis was accepted. Hence, there was an influence of using remedial method of flexible and conventional towards psychomotoric ability on protein, fat and carbohydrate analysis.

Students' learning outcomes on psychomotoric skills were higher due to flexible learning giving more opportunities to students to develop their psychomotoric ability and to give opportunity to students to actively participate in learning process. This meant that the psychomotoric ability of the students who were given flexible remedial learning was higher than the psychomotoric ability of the students who were given conventional remedial learning.

\section{Second Hypothesis}

The value of $F_{B}=4.3882>F_{\text {tabel }}=3.98$, so Ho was rejected. This meant that there was a significant difference between vocational and academic category of orientation on students' cognitive ability on protein, fat and carbohydrate analysis. Anava further tested within the row and showed that Fi.j $=70.0795>$ F0.05 $=3.98$. Therefore, Ho was rejected. This showed that there was a difference between B1 (vocational category of educational orientation) and B2 (academic category of educational orientation). Learning outcomes differences were caused by the flexible learning that has repeated the process of re-learning and provide opportunities for students to be actively involved in the learning process, ask unclear matters, discuss and learn to understand the problems and stages in solving the calculation problems. 
The value of $\mathrm{F}_{\mathrm{B}}=65.83>\mathrm{F}_{\text {tabel }}=3.98$. Therefore, Ho was rejected. This meant that there were significant differences in the educational orientation of vocational and academic category on students' affective ability on the subject of protein, fat and carbohydrate analysis. This was because the affective aspects of learning were related to the feelings, emotions or responses of students to their learning experience. Moreover, students' affective behavior can be demonstrated with attitudes, attention, interest and awareness in learning (Fortier, M.S., 1995). Additionally, students' learning goals as a candidate for Health Analyst Associates who are required to be proficient in carrying out health lab examination will influence affective behavior in the learning process. The value of $\mathrm{FB}=11.13>$ Ftable $=$ 3.98. Therefore, Ho was rejected. This meant that there was a significant difference of influence between vocational and academic orientation category on student psychomotoric ability on protein, fat and carbohydrate analysis.

The results in the table above showed that student who had educational orientation on vocational category had a higher average than students who had educational orientation on academic category. Alternatively, students with a vocational educational orientation had a tendency to have a good sense of skills that mighy encourage the students to better understand the lesson being studied. Understanding the academic/theoretical lesson then applying it is one of the good characteristics of the student with the vocational category. Students, who only understand the theoretical lesson but are not able to apply it, will be greatly affected on the learning achievement.

\section{Third Hypothesis}

Based on the results of double comparison computation with Scheffe method on cognitive ability, it was known that: 1) there was a significant difference of average learning outcomes between the vocational educational orientation with the academic educational orientation $(\mathrm{Fij}=70.0795>\mathrm{F} 0.05=3.98)$. The results of the calculation obtained a score of 60 for vocational and 40 for academic. The basis of weighting scores 60 and 40 was referring to the curriculum of Diploma III Health Analyst in 2010, consisting the percentage of theoretical courses $40 \%$ and practicum $60 \%$. The number of students who had vocational educational orientation in the experimental class were more than 18 people, while the control class had 16 people. It could be concluded that students with vocational educational orientation had a good influence on their cognitive ability; and 2) there was a significant difference of average learning outcomes between flexible remedial learning and conventional remedial learning $(\mathrm{Fij}=$ 21.2277> Ftabel $=3.98$ ). The average of cognitive ability of students who were given flexible remedial learning model was 70,47; while the average of cognitive ability of students who were given conventional remedial learning model was 58,41 . Hence, it could be concluded that flexible remedial learning model provided good influence to students cognitive ability.

The results of two-way variance analysis with unequal cell experimental group (flexible remedial learning) and control group (conventional remedial learning) obtained FAB $=1.9230$ and Ftable $=3.98$. Since FAB $<$ Ftable, then Ho was accepted. This indicated that there was no interaction between the learning model, between flexible and conventional remedials, toward educational orientation on cognitive abilities. This happens when students have clear educational objectives according to their educational level (vocational and academic). Taking any kind of remedy with any learning model (flexible and conventional) will create the same learning achievement.

The result of variance analysis of two paths with unequal cells obtained $\mathrm{FAB}=11.16$ > Ftable $=3.98$. As a result, Ho was rejected. This proved that there found an interaction of learning model between flexible and conventional remedial towards educational orientation on affective ability. The conclusion of this third hypothesis was the interaction of flexible remedial learning model to students with vocational educational orientation result students tended to obtain higher affective achievement than conventional remedial learning model interaction on students with academic orientation. The interaction between flexible remedial learning models in students with academic orientation tended to obtain higher affective achievement than conventional remedial learning model interaction in students with academic orientation. The interaction between flexible remedial learning models in students with vocational educational orientation tended to obtain higher affective achievement than on the interaction of conventional remedial learning model in students who had academic 
educational orientation. Students who had a vocational educational orientation and were given flexible remedial learning earned higher affective learning outcomes. This was due to the attitude, attention, skills and awareness of students in learning which increased because they could identify the learning difficulties they experienced (Harris, R. Asunders, 1981).

Based on the result of two way variance analysis with unequal cell, it was obtained $\mathrm{FAB}$ $=18.16>$ Ftabel $=3.98$. Hence, Ho was rejected. This confirmed that there was an interaction between flexible and conventional remedial learning model towards educational orientation on psychomotoric ability. The conclusion of this third hypothesis was that the interaction of flexible remedial learning model in students with vocational educational orientation tended to gain higher psychomotoric achievement than conventional remedial learning model interaction on students with academic orientation. The interaction between flexible remedial learning models in students who had academic educational orientation tended to obtain higher psychomotoric achievement than conventional remedial learning model interaction in students with academic educational orientation. The interaction between flexible remedial learning model in students with vocational educational orientation, students tended to obtain higher psychomotoric achievement than the interaction of conventional remedial learning model in the students who had academic educational orientation. Also, students who had a vocational educational orientation and were given flexible remedial learning obtained higher psychomotoric learning outcomes. This was due to the fact that flexible learning is based on constructivism approach that is before students are accepting the concepts through the learning process they are considered to have had a certain initial ability. This form of learning can be individual, group or classical learning using self-motivation to self-study, able to learn long time by improving skills and mastery.

\section{Conclusion}

The conclusions obtained from this research are: 1) there are significant differences in learning achievement on the subject of protein, fat, and carbohydrate analysis on the cognitive ability of students between the ones given flexible remedial learning and conventional remedial learning. This means that students who receive flexible remedial learning achieve higher achievement than students with conventional remedial learning; 2) there are significant differences on the subject of protein, fat, and carbohydrate analysis on learning achievement of cognitive aspect between students with the ability of vocational and academic educational orientation; and 3) there is no interaction between the flexible and conventional remedial learning model toward the orientation of vocational and academic education.

The theoretical implication of this research is the orientation of education should provide influence on learning achievement. For more, in order to improve learning outcomes on the subject of protein, fat and carbohydrates analysis, attention should be paid to the more suitable educational orientation, which, in this matter, is the vocational one. This means that students not only understand the theory but also be able to apply it because this lesson requires the students' skills to analyze proteins, fats and carbohydrates.

The use of flexible learning method requires the students to be more accurate in choosing/detecting lesson that has not yet been being understood, so that students know which lesson is considered difficult on the subject of protein, fat, and carbohydrates analysis. On flexible remedial method, students are given different sets of problem depending on the level of difficulty, while on conventional remedial it is considered as a regular remedial learning. All students are considered to have difficulties on the same part so the same set of remedial problem is given.

The practical implication is that educational orientation and teaching method of flexible remedial have an influence on the cognitive ability. Students who are given flexible remedial learning with vocational educational orientation have higher achievement compared to those on conventional remedial learning with academic educational orientation.

\section{References}

Chen,L-H. (2011). Enhancement of Student learning performance using Personalized diagnosis and remedial learning system. Computers and Education Journal. 56(1), 289-299

C-Y.Dai., D-H. Huang. (2015). Casual complexities to evaluate the effectiveness 
of remedial instruction. Journal of Business Research. 68(4), 894-899

Dahar, R.W. (2011). Learning Theories. Jakarta: Erlangga.

Fortier, M.S., Vallerand, R.J. \& Guay, F. (1995). "Academic Motivation and School Performance: Toward a Structural Model". Contemporary Educational Psychology. 20(3), 257-274.

Harris, R. Asunders. (1981). Diagnosis, Remedition and Learns of Control: Effection Immediation adn Retained Achievement and Attitudes. Journal of Experimental Education. 49(9),

Kasran, S.B., Toran,H., \& Amin,A.M. (2012). Issues and trends in remedial education: what do the teacher say? ProcediaSocial and Behavioral Sciences. 47(2012), 1597-1604.

Khouyibaba, S. (2015). Thinking Remedial Courses: Challenges and Teaching Philosophy. Procedia-Social and Behavioral Sciences. 186(2015), 927931.

Prayitno., Mudjiran., Afrizal, \& S. Daharnis. (1997). Alat Ungkap Masalah (AUM PTSDL). Jakarta: Departemen Pendidikan dan Kebudayaan.

Raval, H., Mekenney,S., \& Pieters,J. (2014). Remedial teaching in Indian under- resourced communities: Professional development of para-teachers. International Journal of Education and Development.

http://dx.doi.org/10.1016/j.ijedudev.201 $\underline{4.02 .004}$

Saine, N.L., Lerkkanen,M.K., Ahonen,T., Tolvanen,A., \& Lyytinen,H. (2010). Predicting word-level reading fluency outcomes in three contrastive groups: Remedial and Computer-assisted remedial reading intervention, and mainstream instruction. Learning and Individual Differences. 20(5) 402-414.

Sugiyono. (2010). Metode Penelitian Pendidikan: Pendekatan Kuantitatif, Kualitatif dan $R \& D$. Bandung: Alfabeta.

Taylor,E. (1983).'Orientations to Study'Ph.D thesis, Guilford, University of Surrey.

Tinkers, M.H. (1999). The Flexible Learning Approach to Physics (FLAP). International Journal Science Education. 21(2), 213-230.

Toll, S.W.M., Van Luit, \& J.E.H. (2013). Accelerating the early numeracy development of kindergartners with limited working memory skills through remedial education. Research in Developmental Disabilities. 34(2), 745755 . 